Article

\title{
Introducing a Regulatory Policy Framework of Bait Fishing in European Coastal Lagoons: The Case of Ria de Aveiro in Portugal
}

\author{
Stefanos Xenarios $1,2, *$ (D), Henrique Queiroga ${ }^{3}$, Ana I. Lillebo ${ }^{3}$ and Ana Aleixo ${ }^{3}$ \\ 1 Mountain Societies Research Institute (MSRI), University of Central Asia, 72001 Bishkek, Kyrgyzstan \\ 2 Division of Environment and Natural Resources, Norwegian Institute of Bioeconomy Research (NIBIO), \\ NO-1431 Aas, Norway \\ 3 Department of Biology \& CESAM, University of Aveiro, Campus Universitário de Santiago, 3810-193 Aveiro, \\ Portugal; henrique.queiroga@ua.pt (H.Q.); lillebo@ua.pt (A.I.L.); ana.aleixo@ua.pt (A.A.) \\ * Correspondence: Stefanos.xenarios@ucentralasia.org; Tel.: +996-770-822-195
}

Received: 3 November 2017; Accepted: 2 January 2018; Published: 5 January 2018

\begin{abstract}
The harvesting of bait through digging in coastal mudflats is practiced for recreational and commercial purposes in European coastal systems including the Ria de Aveiro coastal lagoon on the northwest Atlantic coast of Portugal. The scale of harvesting in the Ria de Aveiro has recently increased due to the current economic climate in Portugal, with targeting of the polychaete, Diopatra neapolitana species or "casulo" as it is widely known in the Aveiro region. The national authorities have attempted to control casulo digging by issuing a regulation (Ordinance) in 2014 on the maximum daily catch limit to be caught by each individual. The daily catch limit is intended to represent the Maximum Sustainable Yield (MSY) for casulo beyond which overfishing will occur. The monitoring of the regulatory measures is expected to be conducted through on-site inspections in the digging areas. However, weak law enforcement was noticed, while there is also controversy over the daily catch limit (quota) stipulated by the Ordinance. To this end, the current study attempted to assess digging activities through remote monitoring and random inspections for a better policy enforcement of the national regulation. In addition, different harvesting scenarios were employed through a simplified bioeconomic model to attribute the current and future harvesting trends of bait digging in Aveiro coastal lagoon. The study findings indicate that remote monitoring coupled with some onsite interviews could be a more effective approach for the implementation of the current bait digging policy. Further, the results point to a distinctive discrepancy between the daily catch amount (MSY) introduced by the national legislation and the study findings which should be further scrutinized. The diggers seem to have reached the sustainable harvest identified by the present research. The current economic hardship in Portugal and the low profitability in similar employment sectors will possibly attract more diggers and increase harvesting in the near future. An increased harvest would likely trigger overfishing of $D$. neapolitana with unknown consequences for the population of the species as well as the aquatic ecosystem. The socio-economic and environmental effects are yet to be further clarified with more detailed data and advanced modeling techniques to ensure the sustainability of the activity.
\end{abstract}

Keywords: lagoons; catch estimate; catch per unit effort; bioeconomic modeling; management scenarios; Diopatra neapolitana; Portugal

\section{Introduction}

Bait digging for angling or professional fishing is a common practice in many European lagoons [1-3]. Similar to many European cases, the Ria de Aveiro in Portugal is a coastal lagoon 
where shallow digging for shellfish and baitworm takes place in subtidal and intertidal mudflat habitats. The most lucrative baitworm activity involves the solitary tube worm (Diopatra neapolitana), the catworm (Nephtys hombergii) and the ragworm (Hediste diversicolor). It has been indicatively estimated that the Ria de Aveiro may support a total harvest of approximately 45,173 $\mathrm{kg}^{\text {year }}{ }^{-1}$, or $0.03 \mathrm{~kg} \mathrm{~m}^{-2}$ which corresponded to a revenue of $327,346 \mathrm{EUR}$ year ${ }^{-1}$ for the year 2002 [4]. These benthic macroinvertebrates are caught with the use of artisanal handheld instruments.

The baitworms are sold to local fishing stores or exported to Spanish markets for professional and recreational fisheries [5]. The solitary tube worm D. neapolitana, or casulo as it is widely known in the Aveiro lagoon region, has been traditionally harvested as live bait for use in fishing. Casulo is a sedentary carnivorous polychaete species, $15-50 \mathrm{~cm}$ long, which nests inside a membranous tube buried in intertidal mudflats [6,7] as presented in Figure 1.

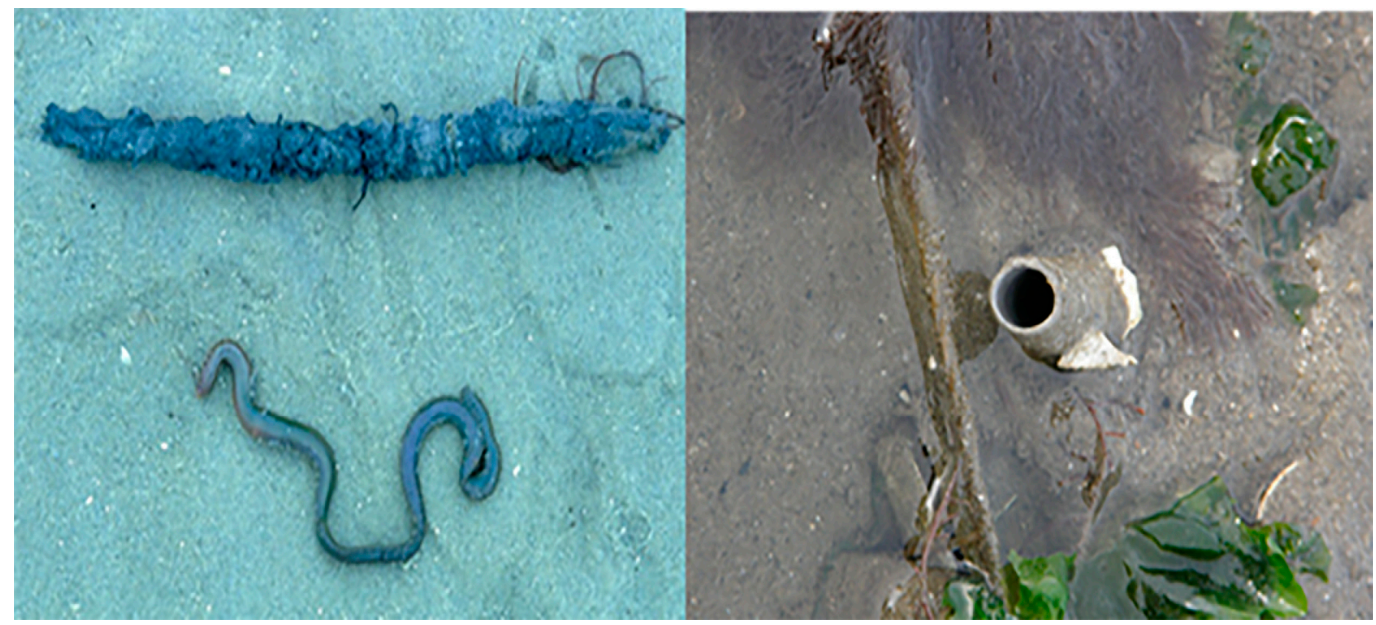

Figure 1. D. neapolitana: polychaete and membranous tube (left); tube buried in the mudflat (right) Photo credit: H. Queiroga and R. Calado.

The net wet weight of $D$. neapolitana can vary from 1 to $9 \mathrm{~g}$ depending on the age and length of the individual, while the tube may weigh an equal amount [6,7]. However, most specimens caught are adults, corresponding to the higher range of the net wet weight. Casulo digging is practiced by individuals, as well as by groups. The diggers may depart from various source points, including small harbors and anchoring sites [5]. Diggers usually cut the anterior part of the worm's body (approximately 10-15 cm) using a hoe or a shovel-like hand-held instrument.

Bait digging is completed when the tide is about to rise and the entire activity lasts approximately $4 \mathrm{~h}$, covering morning or afternoon, depending on the tidal cycle. The diggers cleanse the catches before leaving the mudflats to remove attached sediment. The worms are further separated into groups of 20 to 21 individuals, per unit of sale, wrapped in paper fabric to prevent desiccation and are delivered either to local market or to intermediaries for export purposes.

The recent economic austerity in Portugal has encouraged unemployed and low-income individuals to participate in casulo harvesting as a mean of providing an income and/or supplementing an existing income. The fact that investment and operational costs of bait digging are low in relation to the economic returns means that its popularity is likely to continue, with more individuals expected to join the practice. Casulo digging was initially regulated by a National Ordinance (regulation) issued in December 2010, stipulating that digging for commercial purposes can be practiced only by registered and licensed diggers. A more recent Ordinance was published in January 2014 in an attempt to define the maximum daily catch limit. The daily limit is assumed to reflect the Maximum Sustainable Yield (MSY) of casulo digging while also providing a sustainable income to diggers. According to the Ordinance, the daily catch limit for annelids should be $0.5 \mathrm{~L} \mathrm{day}^{-1}$ per digger, excluding the tube. 
While Aveiro has adopted a quota policy, other bait harvesting management options have been attempted elsewhere. These include bait licensing and the designation of Marine Protected Areas (MPAs) in the United States (US); e.g., Southern California marine reserves [8] and in the United Kingdom (UK); e.g., Fareham Creek—Portsmouth Harbour and Dell Quay_Chichester Harbour [9]. The licensing option in the US has, however, faced significant difficulties in terms of controlling bait harvesting in seashore sites. Limited means of surveillance have impeded efforts to monitor the frequency of bait collectors' visits and the amount of time they spend on baitworm harvesting. Moreover, the appropriate number of licenses that can be issued for ensuring the long-term survival of the species has been difficult to determine [10].

The designation of exclusion zones in the UK (e.g., [11]) for the control of bait harvesting, namely of lugworm, has also raised challenges. MPAs have been created to prevent extensive manual and semi-mechanized bait digging for commercial purposes [9]. Recently, there have also been attempts to assess recreational fishery activities for compliance in marine conservation areas through shore-based remote monitoring systems $[12,13]$. However, it has proven difficult to monitor the frequency and harvesting of bait digging and to differentiate between commercial and personal fishing activities.

Similar challenges are encountered in the case of the quota implementation system in Aveiro lagoon where the local authorities assess the amount harvested through on-site inspections in the mudflat areas. There are no available data on the number of licenses issued locally for shellfish and bait digging (the local authorities cite "hundreds"). Weak implementation of the system results mainly from a variety of reasons. There are insufficient number of officers commissioned at the local Maritime Police delegation for the surveillance of digging activities while there is a complex physiography of the lagoon. The diggers are spread across remote mudflat areas that are difficult to assess; the access points are not well-identified by the inspection authorities and may well change within the year and; the diggers are often informed by word of mouth of the inspections in advance and are thus able to evade the assessments [14]. Furthermore, there is uncertainty over the scientific accuracy of the MSY amount that is dictated by the Ordinance. These challenges have made it difficult for the authorities to identify the volume caught by individuals. The diggers are likely to harvest higher amounts of the daily Ordinance threshold, with unknown effects on the preservation of the species. Also, the inspection of local Maritime Police may last for many days due to the need to investigate the exact amount caught by each digger in remote and hardly accessible mudflat areas.

Significant attempts have been made in Portuguese and other European lagoons to engage bait collectors and other stakeholders in community-based management of natural resources. This engagement is intended to better enforce baitworm control policies and to cultivate an "ownership/stewardship" identity among stakeholders [15]. However, it has not always been possible to identify bait collectors within the local community, while the communities themselves often lack the enforcement capacity to manage the protected areas [16].

Two previous studies have dealt with the catch estimates of casulo digging in Ria de Aveiro during 2001-2002 [4] and 2007-2008 [5] through sampling surveys and on-site monitoring. More broadly, there is also literature on the impacts of bait digging with the use of rudimentary or mechanized instruments in benthic ecosystems [17-20]. The economic implications of baitworm activity for fisheries and conservation management in North European coastal areas have been partly addressed [21-23]. Additionally, the importance of benthic fauna to aquatic ecosystem functions and resilience to external drivers has been explored [24,25].

However, to the best of our knowledge there is not yet a study to investigate the potential of digging effort (hours) and catch monitoring as controlling measures to assess the quotas stipulated by national regulations. In addition, the economic value of baitworm digging and the environmental consequences of potential over-harvesting in the Ria de Aveiro have not been thoroughly identified. In this context, the main objective of the present study is to assess whether remote monitoring complemented with random interviews can significantly improve the current bait digging regulatory policies in European coastal lagoons, by presenting Ria de Aveiro as a showcase. The possible effects of 
tidal trends and seasonal variations in effort and catch are also explored. Further, a static bioeconomic analysis applied trough the development of MSY, Open-Access and Maximum Economic Yield (MEY) scenarios provides some insights on the daily catch amount introduced by the Ordinance.

To fulfill the study objectives the following research questions were addressed: (i) can remote monitoring of the bait digging effort be used as an effective assessment tool? (ii) how are catches affected by digging effort? (iii) how does the open-access scenario reflect the effect of tidal trends and seasonal variations in digging effort and catch? (iv) can MEY scenario explore the potential of exceeding or not reaching the daily catch limitation? (v) how does the MEY scenario matches MSY? (vi) does the static bioeconomic analysis support the quota introduced by the Ordinance?

A main channel in the south of the Ria de Aveiro lagoon, the Mira Channel, was adopted as a study area and a survey was conducted in 2012-2013 to provide the necessary data.

\section{Results}

\subsection{Descriptive Statistics}

The 24 bimonthly remote observations identified 98 individuals practicing digging for $348.75 \mathrm{~h}$ during the period October 2012-December 2013. By interpreting the results per observation round $\left(\sim 4 \mathrm{~h} \mathrm{day}^{-1}\right)$, the mean amount of $4.27(n=24$, standard deviation (SD $\left.=2.23)\right)$ individuals per day was assessed whereas the mean daily effort was estimated at $3.58 \mathrm{~h}_{\text {day }}{ }^{-1}(n=24, \mathrm{SD}=2.39)$.

The net mean wet weight of each unit (baitworm) was estimated at $5 \mathrm{~g}(0.005 \mathrm{~kg})$. The mean daily harvesting for each individual as well as for all diggers per season was counted at 590 baitworms $(n=24, \mathrm{SD}=307)$, which was interpreted as $5.90 \mathrm{~kg}$ day $^{-1}$ including the tubes. The net wet weight per catch is accounted as half of the estimated amount $\left(2.95 \mathrm{~kg} \mathrm{day}^{-1}\right.$ ) (confidence interval (CI) 2.32, 3.57) as the weight of the tube is almost equal to that of the body. The approximate time to reach and leave the mudflats was claimed by the interviewees to be nearly $1 \mathrm{~h}$ each way, including the driving and walking distance to the digging area. The mean first sale price of casulo was estimated at $0.075 \mathrm{EUR}$ per unit with a variation of $\pm 30 \%$.

\subsection{Catch, CPUE and Bioeconomic Results}

The catch and the catch per unit effort (CPUE) findings of the survey during the period 2012-2013 show some distinctive tendencies for the digging activity in Aveiro lagoon. As presented in Figure 2, the mean catch $(\mathrm{kg})$ caught per person for each of the surveyed days is plotted against the number of individuals practicing the digging activity on those days. A statistically significant (F1, $18=2.87$, $p=0.036)$ and associated $\left(R^{2}=0.372\right)$ trend is presented which foresees that the increase of diggers will accordingly trigger an increase in the total catch. The findings are in full accordance with the theoretical background of fundamental fishery economics that indicates increasing catch trends of a fishing species in the short run [26].

The mean daily catch for all diggers was usually higher in spring tides, except in autumn as presented in Figure 3. Daily production was the highest in the summer (ranging from 43 to $29 \mathrm{~kg} \mathrm{day}^{-1}$, in spring and neap tides respectively). Daily production in winter (39 to $21 \mathrm{~kg} \mathrm{day}^{-1}$, in spring and neap tides) and autumn (18 to $26 \mathrm{~kg} \mathrm{day}^{-1}$, in spring and neap tides, respectively) reached intermediate values. The lower values were recorded in the spring season (17 to $10 \mathrm{~kg} \mathrm{day}^{-1}$ for spring and neap tides). Despite the considerable variation in catch values, significant effects of season, tide range and of the interaction were not detected by a 2-way orthogonal analysis of variance (ANOVA) $(p>0.20$ in all cases). 


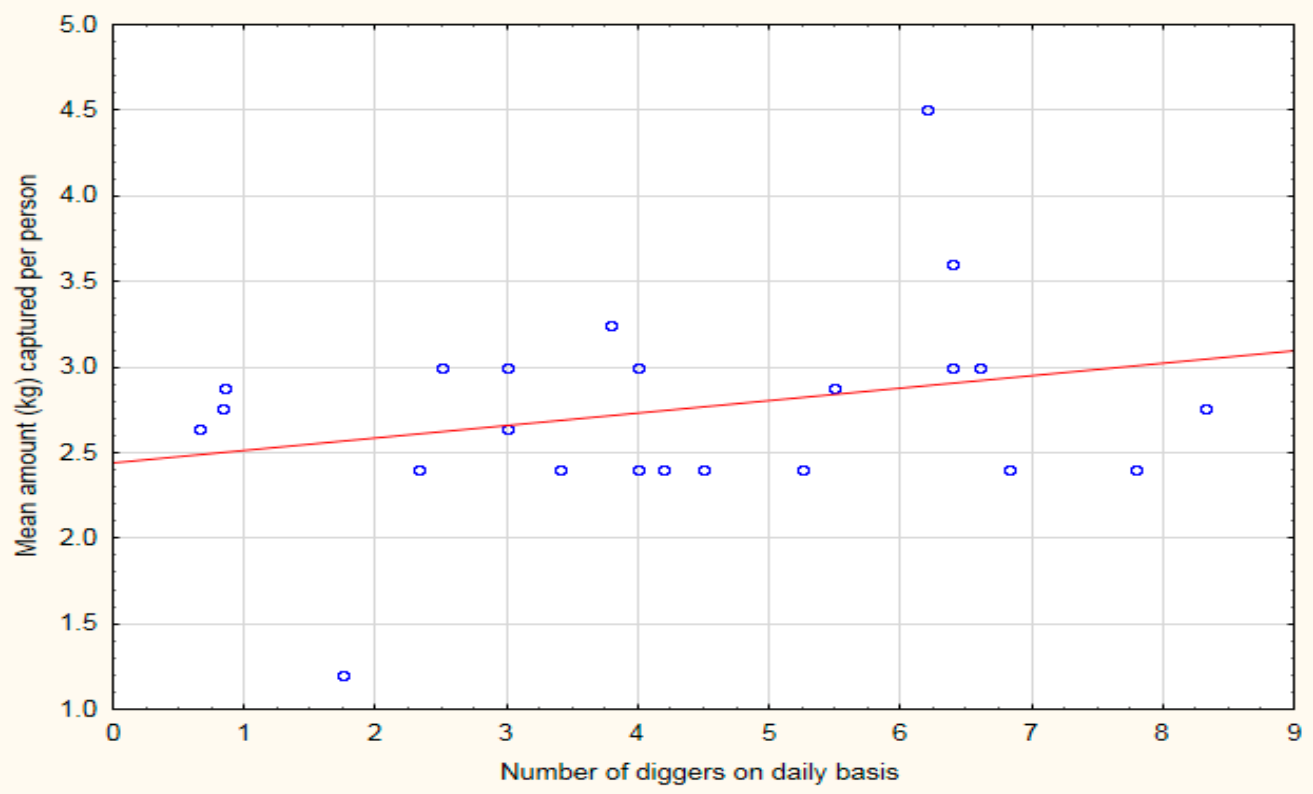

Figure 2. Mean Catch ( $\mathrm{kg}$ ) of casulo as a function of individuals practicing digging in Aveiro lagoon on a daily basis for the surveying period 2012-2013.

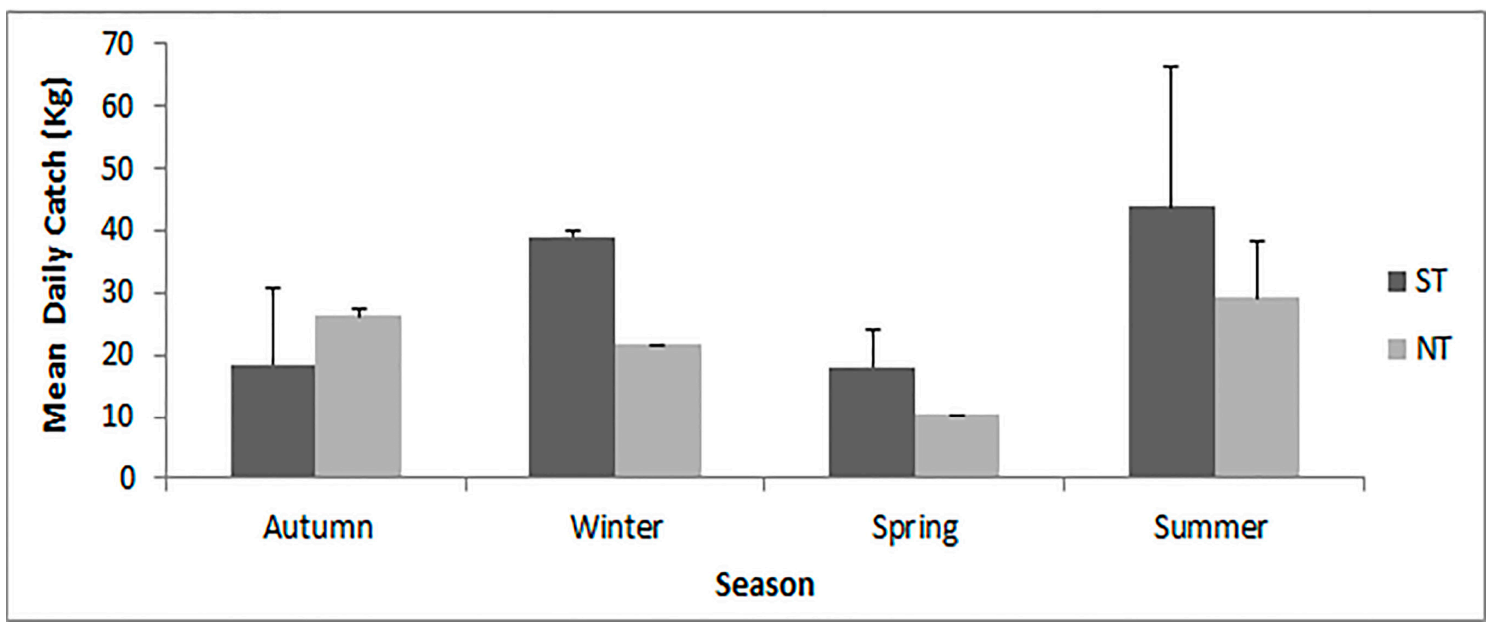

Figure 3. Mean daily catch for seasonal and tidal ranges. ST = spring tide; NT = neap tide. Whiskers show +1 standard error.

In turn, the CPUE as a function of the number of diggers monitored in the surveyed days, is exhibited in Figure 4. As presented, a distinctive and statistically significant $(\mathrm{F} 1,18=0.56, p=0.042)$ downward slope is shown for the period 2012-2013 while an association is also indicated $\left(R^{2}=0.362\right)$. This downward slope suggests that the higher digging effort may decrease the CPUE and hence the economic efficiency and stock reserves of the casulo species.

The CPUE was higher in spring tides, in all four seasons with significant difference in autumn (Figure 5). However, no significant effects of season, tidal range and their interactions on effort were detected with a 2-way orthogonal ANOVA ( $p>0.20$ in all cases). 


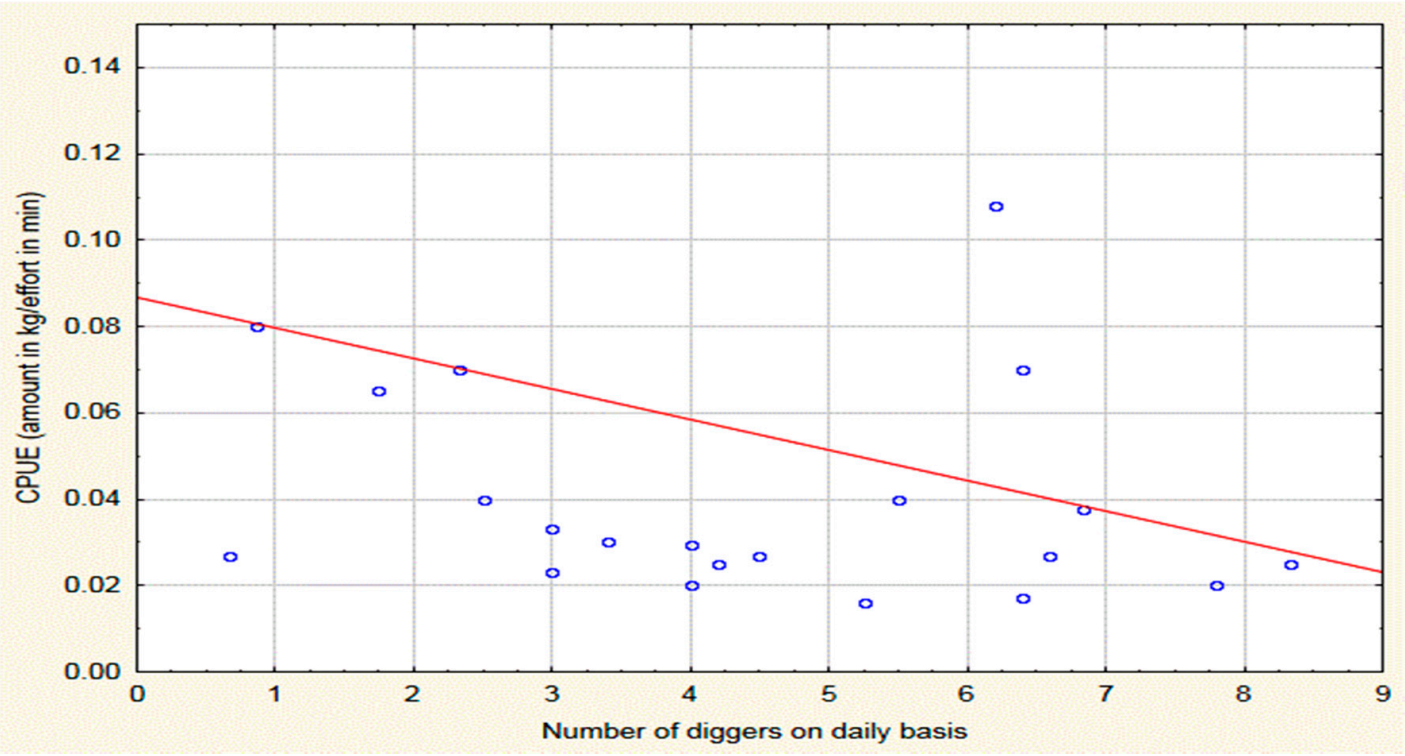

Figure 4. Catc h Per Unit Effort (CPUE) calculated in number of baitworms captured as a function of the number diggers on daily basis in Aveiro lagoon for the surveying period 2012-2013.

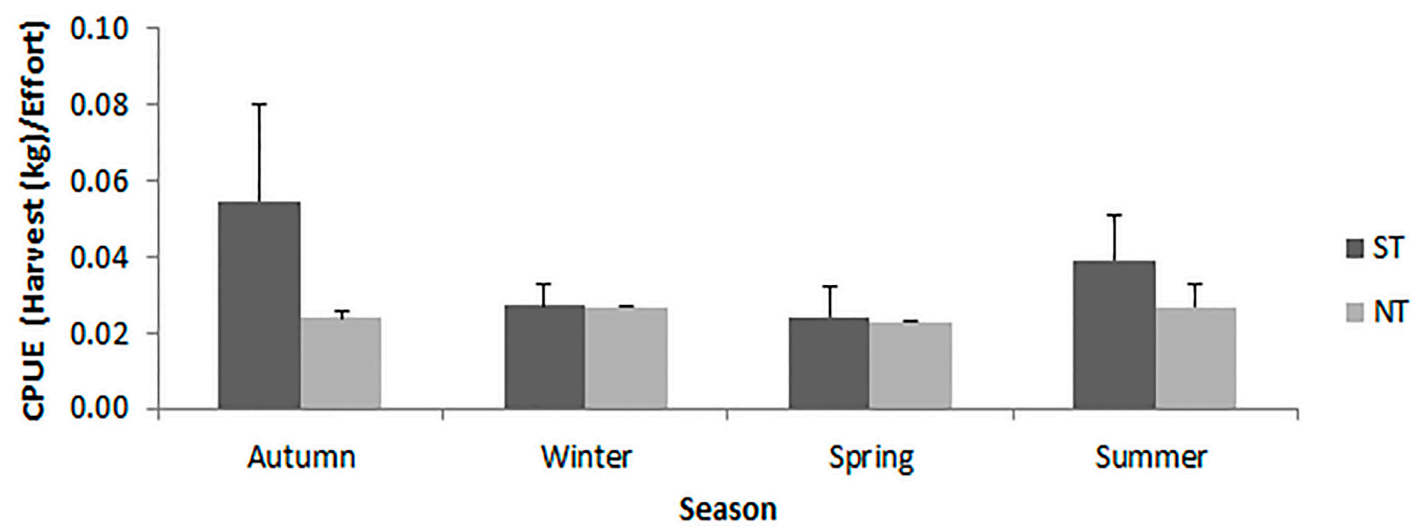

Figure 5. Mean daily values of Catch Per Unit Effort (CPUE) ( $\mathrm{kg} /$ effort) for seasonal and tidal ranges. $\mathrm{ST}=$ spring tide; $\mathrm{NT}=$ neap tide. Whiskers show +1 standard error.

In turn, the three different scenarios were deployed based on the bi-monthly observations of the survey sampling as presented in Figure 6. The open-access scenario is initially identified by the projected intersection of total costs and revenues at a maximum effort $43.84 \mathrm{~h} \mathrm{day}^{-1}$ for all diggers (10.27 $\mathrm{h} \mathrm{day}^{-1}$ per individual). This extensive digging effort was not practiced along the survey in the assessed mudflat areas.

The culmination of total revenues in Figure 6 also traces the MSY at the expense of $18.87 \mathrm{~h} \mathrm{day}^{-1}$ maximum effort for all diggers. At this point, the total digging revenues appear to largely overcome the total costs by attributing a collective profit of $39.93 \mathrm{EUR}^{-1}$ or $9.03 \mathrm{EUR} \mathrm{h}^{-1}$ for each digger. The findings of the MEY scenario are also depicted in Figure 6 where the total revenues surpass the total costs with a high difference by creating a profit of $38.8 \mathrm{EUR} \mathrm{h}^{-1}$ for all diggers or $9.83 \mathrm{EUR} \mathrm{h}^{-1}$ for each digger.

The reaching of the MSY scenario is better illustrated in Figure 7, where the marginal revenues eventually become null. It should be noted that the negative marginal revenues represent actual economic losses. A sustainable digging yield could be attained at a maximum effort of $15.79 \mathrm{~h} \mathrm{day}^{-1}$ for all diggers ( $4.42 \mathrm{~h} \mathrm{day}^{-1}$ for each individual) which is translated to $15.54 \mathrm{~kg} \mathrm{day}^{-1}$ of daily catch for all diggers ( $3.64 \mathrm{~kg} \mathrm{day}^{-1}$ of daily catch for each digger). 


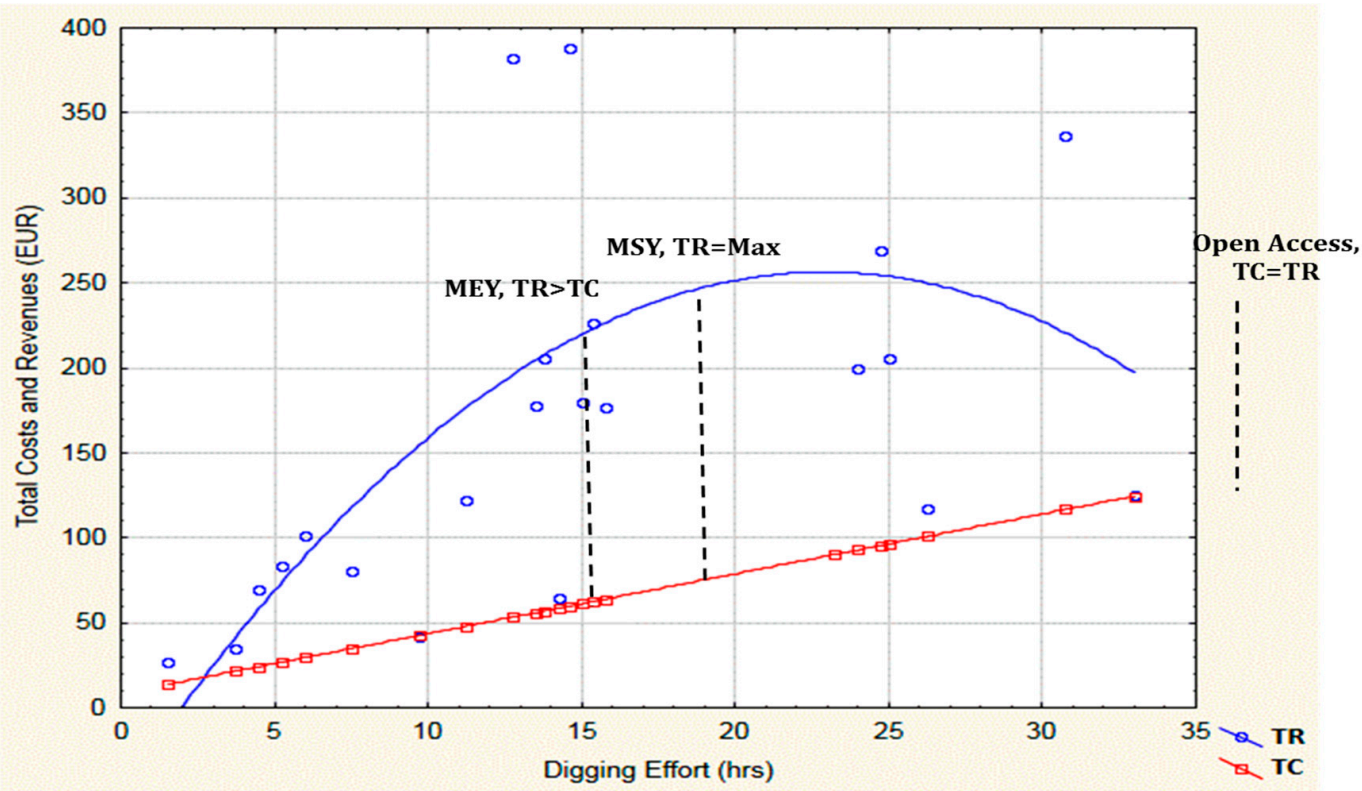

Figure 6. Total revenues and costs against digging effort in Aveiro lagoon for the surveying period 2012-2013. Note: $\mathrm{TC}=$ Total Costs; $\mathrm{TR}=$ Total Revenues; MEY = Maximum Economic Yield; MSY = Maximum Sustainable Yield; MC = Marginal Costs; MR = Marginal Revenues.

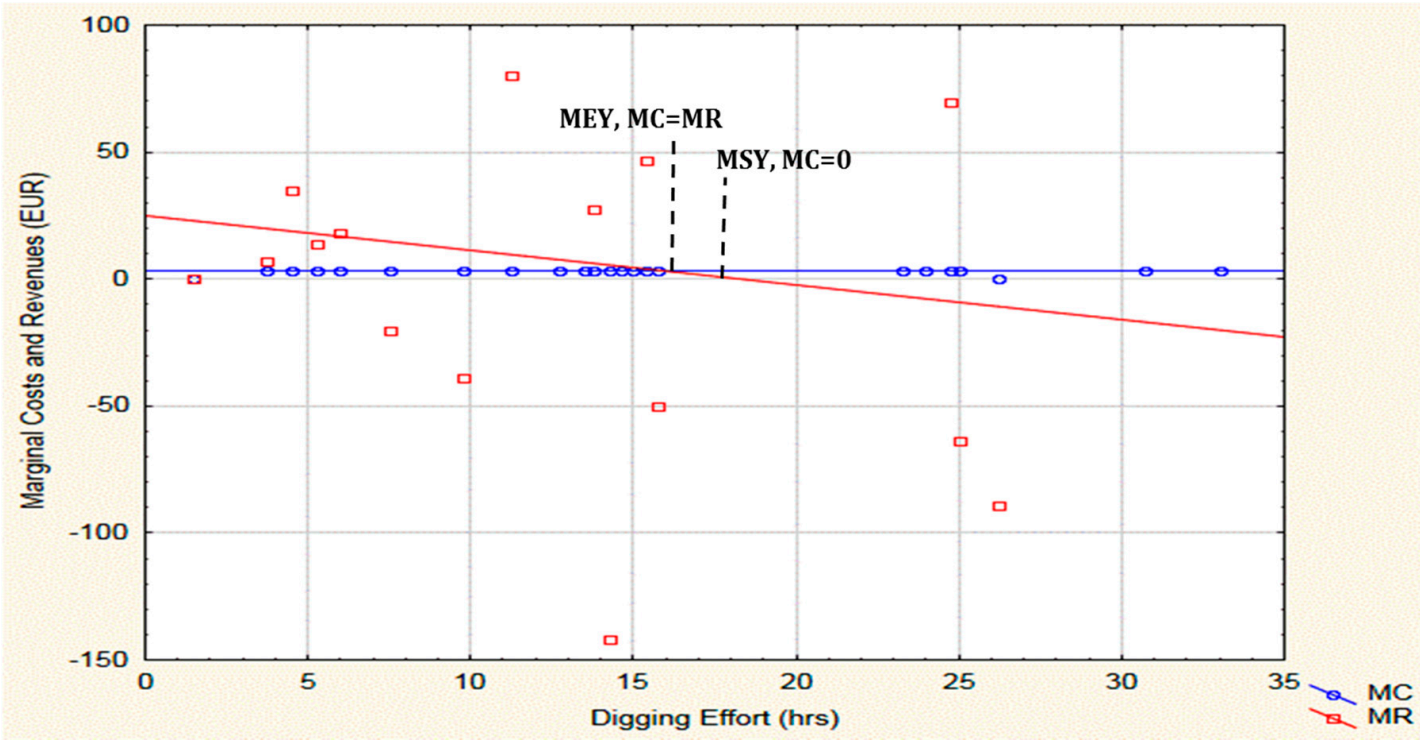

Figure 7. Marginal revenues and costs against digging effort in Aveiro lagoon for the surveying period 2012-2013. Note: MEY = Maximum Economic Yield; MSY = Maximum Sustainable Yield; $\mathrm{MC}=$ Marginal Costs; $\mathrm{MR}=$ Marginal Revenues.

As also better exhibited in Figure 7, there is a considerable number of diggers practicing MEY scenario at a collective effort of $15.05 \mathrm{~h} \mathrm{day}^{-1}$ until the intersection of the marginal digging revenues and costs. On an individual level, the maximum effort for each digger corresponds to $3.94 \mathrm{~h}^{\text {day }}{ }^{-1}$ and can be interpreted as a harvesting of $3.24 \mathrm{~kg} \mathrm{day}^{-1}$ on a daily basis.

\section{Discussion}

Results will be discussed following the initially defined research questions, specifically: (i) can remote monitoring of the bait digging effort be used as an effective assessment tool? (ii) how are 
catches affected by digging effort? (iii) how does the open-access scenario reflect the effect of tidal trends and seasonal variations in digging effort and catch? (iv) can MEY scenarios explore the potential of exceeding or falling below the daily catch limitation? (v) how does the MEY scenario matches MSY? (vi) does the static bioeconomic analysis support the quota introduced by the Ordinance?

\subsection{Can Remote Monitoring of the Bait Digging Effort Be Used as an Effective Assessment Tool?}

The current study suggested the monitoring of digging effort as a better controlling measure to assess the maximum harvesting amount of baitworm in Aveiro lagoon. Our survey experience indicated that the remote monitoring of digging effort coupled with random interviews was less time-consuming than counting the harvesting amount through on-site inspections as requested by the current policy framework.

Additionally, bait diggers were sometimes hesitant to reveal their actual harvesting count, which further aggravates the implementation of the Ordinance for the regulation of baitworm activity. Other studies highlight the need for appropriate educational methods for bait diggers to understand the related environmental policy and adequate regulation enforcement (e.g., [7]).

\subsection{How Are Catches Affected by Digging Effort?}

The nearly proportional increase of the amount caught and digging effort displayed in Mira Channel may not initially trigger any concern on the economic prosperity of the activity of the species. A maximized digging effort seems in the first instance to attribute higher yields and subsequently encourage more individuals to practice casulo digging. The proportionally increased yield to effort seems to particularly favor the new diggers seeking profit maximization in a short-term period without having prior experience in this activity. As noted by the respondents in the on-site interviews, the economic situation in Portugal has recently attracted a large proportion of opportunistic diggers, who have a less fine-tuned exploitation strategy than experienced diggers who merely need additional income. It should be noted that the population trends of Aveiro town within the last decade do not seem to play a significant role in the higher presence of opportunistic diggers. According to the Portuguese National Statistics (INE) [27] the population increase mostly reflects the overall tendency also seen in other urban centers of Portugal.

Contrary to the nearly proportional increase of effort and catch in Figure 4, the CPUE findings suggest that a decreased amount of yield comes along with the extension of the digging effort. Although the results represent only a yearly monitoring period, a gradual CPUE slowdown may signal the need for more well-designed policies on baitworm digging. No significant difference of season, tide range and their interaction was detected in the catch and CPUE contrary to findings from two previous studies conducted in 2001-2002 [4] and in 2007-2008 [5].

The lack of significance may also be attributed to the opportunistic bait digging practiced especially by new diggers who are not aware of the tidal and seasonal effects on harvesting. The mean net weight per catch of $2.95 \mathrm{~kg} \mathrm{day}^{-1}$ in the present study is moderately lower than the values of $4.56 \mathrm{~kg}$ day $^{-1}$ and $3.7 \mathrm{~kg}$ day $^{-1}$ calculated at 2001-2002 [4] and 2007-2008 [5] studies. More detailed-time series would be requested to argue for a gradual decrease of the casulo catch along the years and the potential reasoning. However, the findings signal the need for a more thorough research on the casulo stock reserves in Aveiro lagoon.

\subsection{How Does the Open-Access Scenario Reflect the Effect of Tidal Trends and Seasonal Variations in Digging Effort and Catch?}

Results showed that despite the recorded variations, digging effort and catches were not significantly affected by season, tidal range and their interactions. The results from the open-access scenario suggest a maximum digging effort per individual at $10.27 \mathrm{~h} \mathrm{day}^{-1}$ beyond which no more profits are generated while the casulo reserves are nearly depleted. The findings indicate that the open-access scenario was not reached during the surveyed period. As mentioned, the survey has 
captured the daytime activities of each digger, which were confined to the tidal time period of approximately $4 \mathrm{~h} \mathrm{day}^{-1}$.

Therefore, the maximum daily effort of $10.27 \mathrm{~h} \mathrm{day}^{-1}$ described in the open-access scenario could hardly be attained. The observations in previous surveys in 2001-2002 and 2007-2008 [4,5] mention that bait diggers may also work in a second tide during spring and summer seasons. This is bound to occur when there are two high amplitude low tides during daylight hours (very early in the morning and in the early evening), or during low tides at night.

Other research findings, however, have also indicated that rather low yields were recorded along the second tide in these two seasons [28]. The low yields and hence low profits tend to discourage diggers from practicing the activity in the second tide or to conduct only a few more hours (1-2) of bait digging. It is unlikely that even the inclusion of the second tide's harvest would result in a pooled maximum effort of $10.27 \mathrm{~h}_{\text {day }}^{-1}$ as proposed in the open-access scenario. However, no systematic survey has been conducted yet to account for a second daily tide and this should be explored in future studies.

\subsection{Can MEY Scenario Explore the Potential of Exceeding or Falling below the Daily Catch Limitation?}

The maximum sustainable yield scenario revealed a $4.42 \mathrm{~h}^{\text {day }}{ }^{-1}$ effort per individual which could be interpreted in $3.64 \mathrm{~kg}_{\text {day }}{ }^{-1}$ for each digger. The suggestive amount seems to be far higher than the $0.5 \mathrm{~L} \mathrm{day}^{-1}$ stipulated by the Ordinance and raises concerns on the scientific background of the indicated amount. The research findings may be differentiated if more observations from the entire lagoon will be included and longer-time series become available. However, the large deviations between the survey results and the Ordinance threshold should be well scrutinized in future research studies.

The diggers seem not to surpass the digging effort of $4.42 \mathrm{~h}^{\text {day }}{ }^{-1}$ detected by the MSY scenario. In effect, the maximum effort in the MSY scenario gives the impression that the daytime tidal period (approx. $4 \mathrm{~h} \mathrm{day}^{-1}$ ) may protect the casulo stock against overexploitation. It should be noted, however, that all three scenarios are based on a static bioeconomic analysis where the environmental and economic pressures over time are not contemplated. The MSY effort levels may substantially change in the medium term by questioning the assumed insurance provided by the tidal period.

We may consider, for instance, that bait diggers would like to increase harvesting output and income by investing in better gear and equipment in subsequent years. Equipment upgrades are common for improved harvesting of other macrobenthic communities (clams, cockles) in many coastal areas of Europe [29]. Likewise, diggers could invest in hand-dredge equipment, which is widely used for cockle harvesting in south European mudflats similar to Aveiro Lagoon [30]. The economic benefits stemming from the use of such equipment upgrades are claimed to bring a two to fourfold yield increase in similar settings [31,32]. In our case, a new hand-dredge is expected to attribute a moderate twofold harvest increase due to the semi-mechanization of the digging activity.

However, the same price should initially hold for casulo per unit as before the equipment upgrade. The increased yield in the small market of Aveiro is highly likely to entail excess supply of the D. neapolitana species, even if some of the harvested amount will be met by external (Spanish) market demands. The oversupply will, in turn, exert high pressures in lowering the price offered to diggers by substantially decreasing their profits. Similar cases with the trading of other macrobenthic community species have shown that a twofold increase in supply may eventually lead to a $30-50 \%$ decrease in the initial price [33,34]. In our case, we anticipate that the twofold harvesting increment could signal a $40 \%$ reduction in the initial value, due to oversupply.

The price reduction would probably lead to a decrease in bait digging activities in the longer term, although excessive harvesting would continue for a considerable time period. The above example underlines the need for a cautionary approach to the management of bait digging for the avoidance of overharvesting practices. More detailed and longer time-series are needed to better estimate the environmental and economic sustainable harvesting levels through a dynamic modeling analysis. 


\subsection{How Does MEY Scenario Matches MSY?}

In case the maximum digging effort is assumed to be exerted daily for both scenarios, then the monthly net revenues (income) for each individual would be $1198 \mathrm{EUR}^{\mathrm{month}}{ }^{-1}$ for the MSY scenario and 1164 EUR month ${ }^{-1}$ for the MEY scenario. This difference would imply a profit difference (34 EUR month ${ }^{-1}$ ) in favor of the MSY option. It is noted, however, that the profit difference is provoked by a more extensive digging effort $\left(4.42 \mathrm{~h} \mathrm{day}^{-1}\right)$ in MSY over the MEY $\left(3.94 \mathrm{~h} \mathrm{day}^{-1}\right)$ scenario. If profits are counted on an equal digging effort, then MEY would be a more profitable option given the higher hourly earnings $\left(9.83 \mathrm{EUR}^{-1}\right)$ in comparison to the MSY $\left(9.03 \mathrm{EUR}^{-1}\right)$ case.

We may assume that a new regulatory policy endorses the MEY scenario to confront the anticipated harvesting increase over time as shown in the previous example with the new purchased equipment (Section 3.4). In this case, the digging activity will render a monthly income of $1164 \mathrm{EUR}^{\mathrm{month}}{ }^{-1}$ for MEY and 1068 EUR month ${ }^{-1}$ for MSY scenarios by attributing a profit difference of $96 \mathrm{EUR}^{\mathrm{month}}{ }^{-1}$ in favor of the MEY scenario this time. The profit difference suggests that the MEY scenario could offer significant earnings by improving the environmental sustainability of casulo reserves in the long run.

\subsection{Does the Static Bioeconomic Analysis Support the Quota Introduced by the Ordinance?}

The catch results indicate that although the total yield may proportionally increase with the digging effort in the short-term period, the CPUE may decrease along a higher digging effort. The CPUE trends should be contemplated for the designing of a harvesting policy on baitworm activities in Aveiro lagoon. In addition, the decrease of the amount caught per individual along the three observation years (2001-2002, 2007-2008, 2001-2013) should be further elaborated in future studies.

The high discrepancy between the MSY amount $\left(3.64 \mathrm{~kg} \mathrm{day}^{-1}\right)$ traced between our model and the Ordinance $\left(0.5 \mathrm{~L} \mathrm{day}^{-1}\right)$ should be further explored through the inclusion of more biological parameters in dynamic modelling studies. The research findings suggest that the depletion of D. neapolitana implied in an open-access scenario is unlikely to occur thanks to the tidal constraints. However, the maximum sustainable economic and environmental thresholds defined in the bioeconomic analysis seem to have already been reached.

Labor market effects, future baitworm demand by local and international markets and the potential harvest increase through mechanical devices should be acknowledged in future assessments [35-37]. Adding other major environmental and biological factors, such as hydrological trends between the marine and freshwaters, sedimentation dynamics in the lagoon, species interaction and the ecosystem carrying capacity, would enhance modeling precision [37-42]. Also, a comparative analysis between the quota-based approach of Aveiro and other case studies focusing on licensing and protected zoning areas would be of major value for the better evaluation of the study findings.

\section{Materials and Methods}

\subsection{Study Site Description and Survey Design}

The Ria de Aveiro $\left(40^{\circ} 38^{\prime} \mathrm{N}, 08^{\circ} 45^{\prime} \mathrm{W}\right)$ is a shallow coastal lagoon located on the northwest coast of Portugal, connected to the Atlantic Ocean through a single inlet (Figure 8). The lagoon forms a mesotidal wetland area characterized by four main channels with several branches forming islands, inner basins and mudflats. The two narrow and elongated Mira and Ilhavo Channels in the south are approximately $25 \mathrm{~km}$ and $15 \mathrm{~km}$ long, respectively. In the center, the Espinheiro Channel stretches for nearly $17 \mathrm{~km}$ while in the north the S. Jacinto-Ovar Channel runs $29 \mathrm{~km}$ in length.

Overall, the lagoon encompasses nearly $45 \mathrm{~km}$ in length (NNE-SSW) and $10 \mathrm{~km}$ in width. However, the lagoon ranges from approximately $83 \mathrm{~km}^{2}$ and $66 \mathrm{~km}^{2}$ at high (tide) and low (ebb) water levels, respectively. According to the 2011 census [27] the watershed area is home to a population of 353,688 people. In the town of Aveiro, there are 245,000 inhabitants with a population density of over 275 inhabitants $\mathrm{km}^{-2}$, which is more than twice that of mainland Portugal [28]. The major economic sectors are agriculture (cattle, horticulture), industry (chemical, metallurgical, paper, furniture), 
commerce and tourism. The per capita purchasing power in the region is $96 \%$ of the national per capita purchasing power [27]. There is a population growth trend which is set to continue, however at lower rates during the next decade. The census data from 1991 to 2001 shows a population increase of $10.4 \%$, which fell to $9.4 \%$ in the period $2001-2011$ and is expected to decline further to $8.6 \%$ for the period 2011-2021.

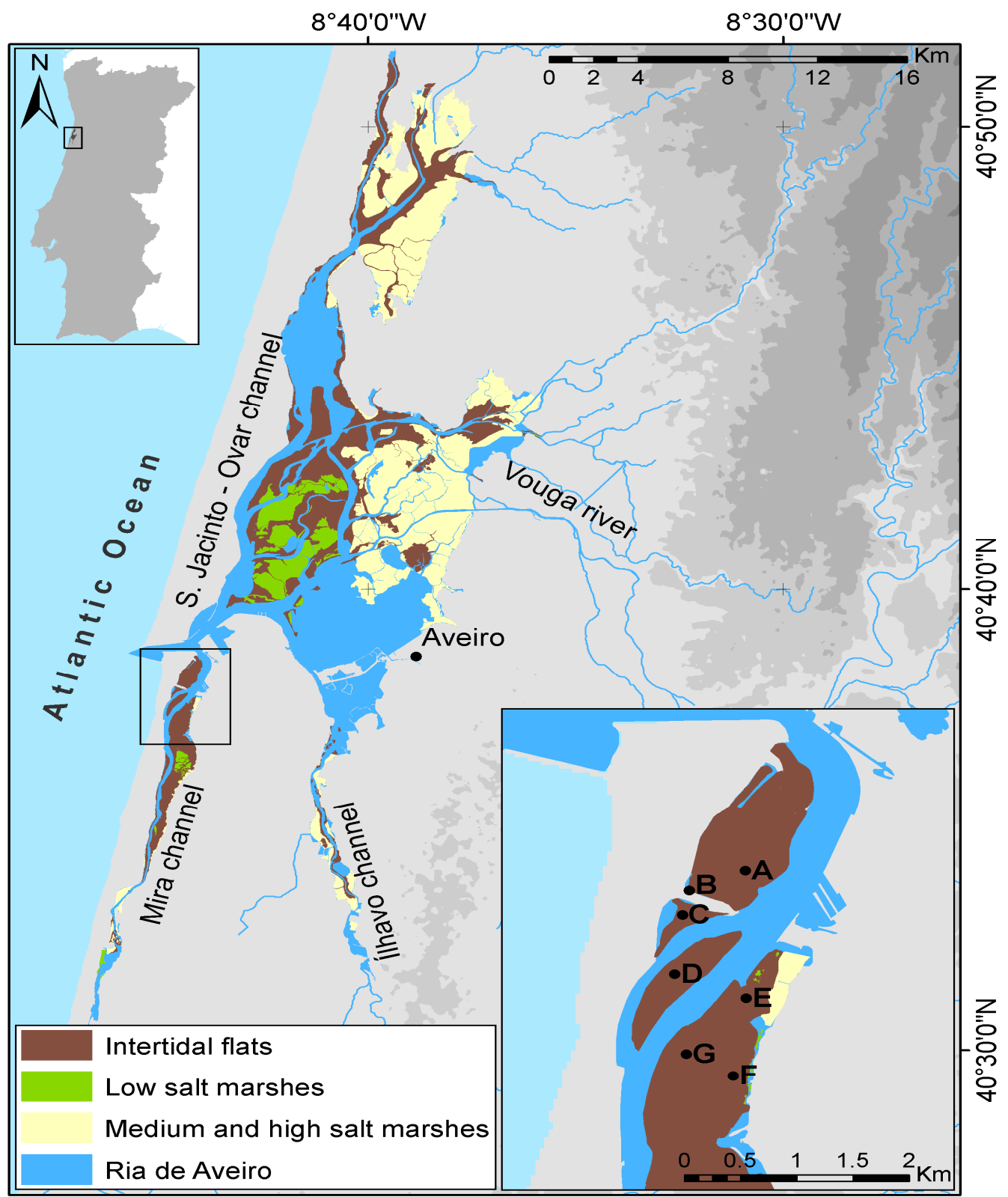

Figure 8. The Ria de Aveiro coastal lagoon, main channels and primary habitats (habitats shapefiles provided by AMBIECO/PLRA [43]). Map generated with ArcGIS 10.2 Software (Esri, Redlands, CA, USA) (http://www.esri.com/software/arcgis/arcgis-for-desktop). Credits of World Terrain Base: USGS-Land Processes Distributed Active Archive Center; Direção Geral do Território; Portuguese Environmental Agency (APA) and updated AMBIECO/PLRA habitats shape-file.

The Ria de Aveiro lagoon lies in a temperate zone and baitworm catch can vary seasonally. In addition, there are strong tidal effects, which may allow or obstruct accessibility to digging grounds and affect the behavior of the target species. The average tidal range is approximately $2 \mathrm{~m}$ according to the National Hydrographic Institute of Portugal, distinguished between neap and spring tides [28]. 
Spring tides (tidal range $>2 \mathrm{~m}$ ) expose a larger mudflat area and allow more intensive bait digging. During neap tides (tidal range $<2 \mathrm{~m}$ ) many mudflats are submerged, limiting digging activity [28].

The casulo digging is conducted in the Mira Channel in the south and in the S. Jacinto-Ovar Channel in the northern parts of the lagoon. A survey was conducted bimonthly between October 2012 and December 2013 to monitor the casulo activities in the Mira Channel, south of the lagoon. The survey frequency (bimonthly) was decided based on similar survey patterns followed by two previous studies during 2001-2002 [4] and 2007-2008 [5] in Ria de Aveiro. There was also an attempt to monitor casulo activities along the S. Jacinto-Ovar Channel in the north. However, most of the casulo populations were situated on islands that are difficult to reach and thus were excluded from the present study.

The survey dates in the study area (Mira Channel) were chosen randomly but were constrained so that a balanced number of survey dates were allocated to spring and neap tides within each season. Two survey observers were recruited to count the number of diggers at specific observation points every $45 \mathrm{~min}$ along a determined route on the Mira Channel so as to cover the surveyed area. The observation points were reached by car or by boat and binoculars were used to count the number of diggers operating on the mudflats. The observation points are presented through capital letters $(\mathrm{A}, \mathrm{B}, \mathrm{C}, \mathrm{D}, \mathrm{E}, \mathrm{F})$ in the right bottom end of Figure 8.

Monitoring began immediately before the bait diggers entered the mudflats while the areas were still inundated. The observers conducted 3 to 4 complete circuits per day and the entire monitoring process took about $4 \mathrm{~h}$ per day, starting 1-2 $\mathrm{h}$ before and ending $1-2 \mathrm{~h}$ after each low tide. The diggers were unaware of the surveying process so that they naturally behave without over or underperforming along the digging activities. However, the surveying process was conducted in prior communication with the local fisheries' association (Associação de Pesca Artesanal da Ria de Aveiro) with the University of Aveiro along the framework of national and EU-funded projects. The University has also contacted the Head of Aveiro Port who is the authority on matters related with surveillance, security and safety in the lagoon. Both the association and port authority have verbally expressed their approval and support for the study.

In addition, upon completion of the activity, the survey observers conducted random interviews with diggers. One interview was conducted for each survey date (bi-monthly observation) which accounted for twenty-four (24) interviews in total for the entire surveying period. The interviews were held in different places each time so as to avoid querying the same persons and to acquire information from as many diggers as possible. The duration of the interviews was 15-20 min each. All the individual interviews were made after verbal consent with the diggers and was mentioned that the questionnaire would be anonymous.

The interviews elicited basic socio-demographic data of the respondents along with some aspects of digging activity such as digging frequency, duration, catch selling sources and pricing as presented in Appendix A. It was acknowledged that the respondents may be reticent on sharing information and manipulative in providing answers intended to be viewed favorably by the interviewers [9]. In this regard, we have crosschecked their responses about the digging frequency and duration through the onsite monitoring results while for the market related data we have also consulted intermediaries dealing with baitworm exports as well as local fishing stores. In addition, the total catch was recorded based on the counts of the bucket's content or on digger's declarations followed by visual inspection of the bucket. Further, random catch samplings were weighted in every 3-4 interviews to capture the mean value per unit (baitworm).

\subsection{Fishing Effort and Maximum Sustainable Yield Estimations}

Given the biology of the species and the catching technique, the term digging effort (E) is adopted in this study instead of the usual fishing effort term used in fisheries biology. To identify the digging effort, we applied the progressive counting method of Hoenig et al. [44] based on the observations of the survey. Recruited survey observers should conduct a repeated route in a target area and count 
all diggers throughout the day as presented in the previous section. The Effort (E) spent for casulo digging was estimated based on the distribution of diggers (counts) over time and is algebraically expressed as

$$
\mathrm{E}=\mathrm{D} \times \mathrm{HRs}
$$

where $\mathrm{D}=$ Diggers, $\mathrm{HRs}=$ Hours .

The data for both the distribution of individuals and the digging hours were collected from the monitoring survey in the Mira Channel. We further estimated the CPUE through the data drawn from the on-site interviews based on the method of Pollock et al. [45] in which bait diggers were randomly selected and interviewed after the digging session had ended. It is noted that CPUE is an indicator frequently used to interpret the biomass trends in fish species. As mentioned by the Food and Agriculture Organization [46] the CPUE measures "the quantity of fish (casulo in our study) caught (in number or in weight) with one standard unit of fishing (digging in our study) effort". CPUE could be used as a measure of the economic efficiency of digging activity as well an indicator of the casulo biomass trends in Aveiro lagoon. CPUE was expressed in number of polychaetes caught per digger per hour and is algebraically presented as below:

$$
\mathrm{CPUE}=\mathrm{C} / \mathrm{D} \times \mathrm{HRs}
$$

where $\mathrm{C}=$ Catch, $\mathrm{D}=$ Diggers, HRs $=$ Hours.

We also inspected the effects of seasonal and tidal range on the effort of individual diggers through a 2-way orthogonal ANOVA. Whenever necessary, the data were log-transformed to homogenize variances.

A maximum sustainable yield scenario was elaborated to estimate how much digging effort should be exerted for the implementation of the Ordinance. In turn, an open-access scenario was developed where the potential of the diggers exceeding the MSY was investigated. By translating this into digging effort, the highest amount of time to be potentially spent on the activity was calculated. Additionally, a MEY scenario inspected the potential of smaller digging efforts in the mudflats with, however, higher economic returns.

A simplified and static bioeconomic model was designed to detect how the surveyed diggers perform in relevance to the three scenarios. While we acknowledge that the suggested model may oversimplify the economic and environmental sustainability of baitworm digging in Aveiro lagoon, we believe that the predictions of this model are useful to bracket the possible management options for this fishery in the Ria de Aveiro, given the current data limitations and by the fact that it includes the best available scientific knowledge.

The adopted model assumes that a logistic (sigmoidal) growth is followed by the D. neapolitana species. It is understood that in order to demonstrate that a natural population follows a logistic growth pattern it is necessary to record the population density on multiple occasions across time and inspect if the rates of change depend on population density. We also acknowledge that the logistic growth entails many important assumptions including: (i) the relation between density and rate of population increase is linear; (ii) the effect of density on rate of population increase is instantaneous; (iii) the environment is constant; (iv) all individuals reproduce equally; and (v) there is no immigration and emigration [47].

Unfortunately, to the best of our knowledge the requested information is not available for D. neapolitana and we could not collect such detailed primary data along the survey period. On the other hand, other studies with similar data limitations consider that the logistic growth dictates that every individual within a population has equal access to resources and an equal chance for survival, so that the contribution of each individual to the population is (approximately) uniform [48].

In our case, D. neapolitana is an intertidal, sedentary, omnivorous species that hides deep in its burrow at low tide and feeds during high tide [7,49]. Apart from small differences in depth distribution (individuals living close to the extreme low water level have more time to feed but are presumably 
more susceptible to predation by fish) we are not aware of any habitat feature that might lead us to suspect that individual growth and mortality might differ considerably among individuals. We assume therefore that the population follows a logistic growth pattern, such as what happens with many animal populations although some variances may occur [50,51]. Furthermore, a similar logistic growth pattern has been presented in previous studies of shellfish and other marine invertebrates, including polychaetes species [52]. The adopted scenarios are diagrammatically presented in Figure 9.

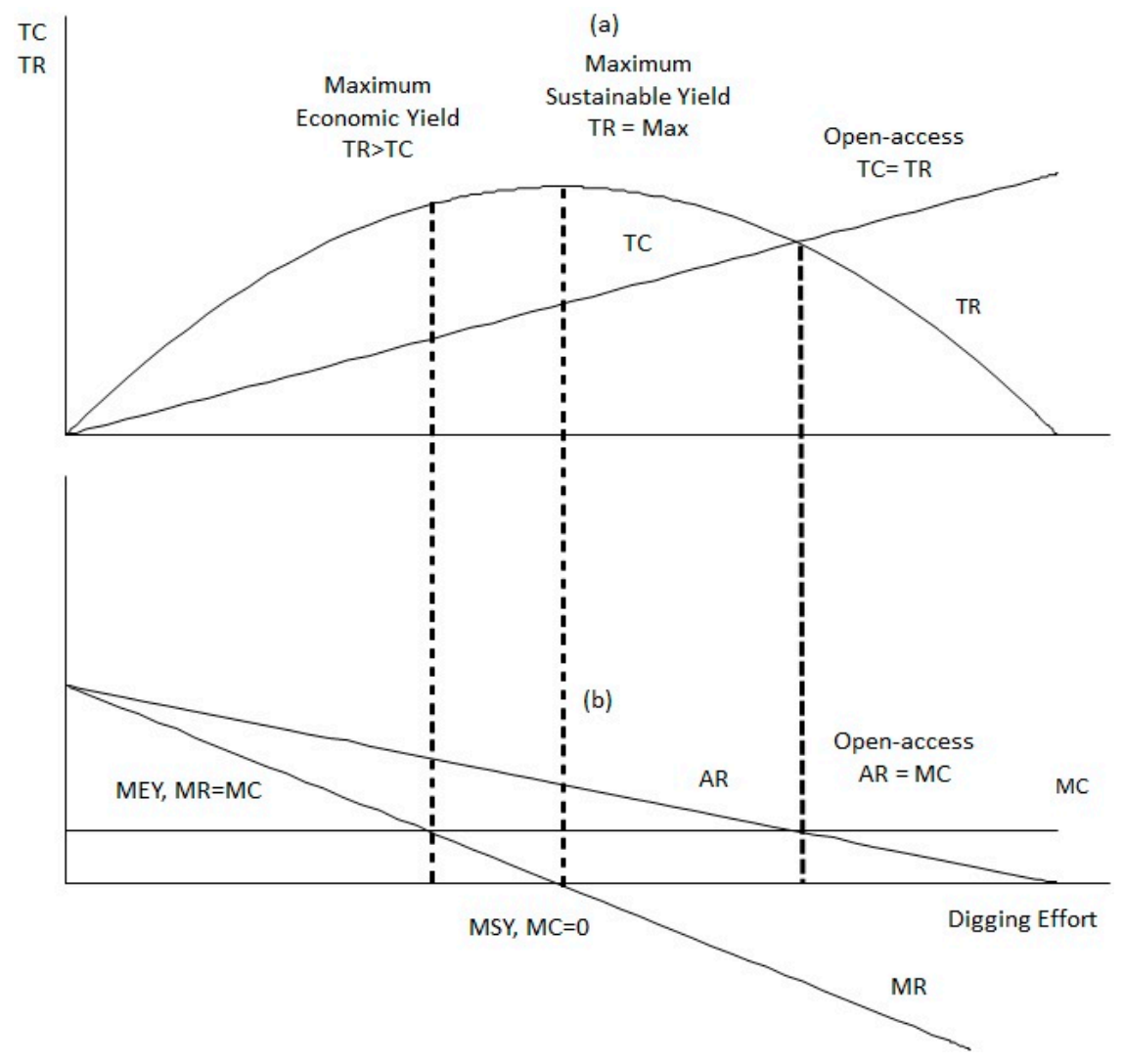

Figure 9. Digging Effort and Economic-Environmental Implications of baitworm fishing in the Aveiro Lagoon. Subfigure (a) presents the performance of Total Costs and Revenues under the Open-Access, Marginal Sustainable Yield (MSY) and Marginal Economic Yield (MEY) scenarios while subfigure (b) shows the trends of Marginal Revenues and Costs and Average Revenues under the same scenarios. Source: Flaaten [53] modified with permission from Ola Flaaten, Fisheries Economics and Management; published by Bookboon, 2016. Note: TC = Total Costs; TR = Total Revenues; MEY = Maximum Economic Yield; MSY = Maximum Sustainable Yield; MC = Marginal Costs; MR = Marginal Revenues, $\mathrm{AR}=$ Average Revenues.

The total revenues curve in Figure 9a simultaneously presents the logistic growth for D. neapolitana species following a bell-shape pattern [54]. In algebraic terms, the total revenues are presented as follows:

$$
\mathrm{TR}=\mathrm{p} \times \mathrm{H}
$$

where $\mathrm{p}$ is the price and $\mathrm{H}$ is the catch dependent on the effort $\mathrm{E}$.

The price of casulo bait was assumed to be constant during the survey period while the catch amount was captured by the interviews and visual inspections along the survey, as previously described. The total costs are delineated by an upward straight line as a function of fixed and variable cost components [55]. The total costs were calculated through the following formula:

$$
\mathrm{TC}=\mathrm{FC}+\mathrm{VC}
$$


where FC are Fixed costs and VC are Variable costs. In our case, the fixed costs of the casulo harvest included equipment, generally a shovel and a $10 \mathrm{~L}$ bucket. The variable costs included travel and labor expenditure. Transportation expenses required to reach and leave the bait digging areas were estimated. Labor costs were calculated based on the opportunity costs of a digger being employed as an unskilled worker on an hourly basis in a similar economic sector. The average (AR) and marginal (MR) digging revenues and marginal costs (MC) determine the three adopted management scenarios, as presented in Figure 9b. The relevance of the marginal values with the total digging costs (TC) and revenues (TR) is shown in Figure 9a. The marginal costs in this simplified bioeconomic model are indicated by a steady horizontal line, which reflects the homogenous and constant expenditures borne by each individual. In our study, the marginal costs were deemed to be equal among the diggers since each person was equipped with the same equipment and travelled approximately the same distance to reach and leave the mudflat areas.

The average and marginal digging revenues in the suggested model follow the same patterns underlined in the production-function theory [56]. In simple terms, the higher the digging effort in terms of hours spent, the lower the average and marginal digging revenues should become for each individual. The profits or net revenues are calculated by subtracting total costs from total revenues as below:

$$
\mathrm{P}=\mathrm{TR}-\mathrm{TC}
$$

The daily catch limit (MSY scenario) pursued by the current policy (Ordinance) for casulo digging cannot be achieved beyond the point where the marginal digging revenues become null, as presented in Figure 9b. Economic and environmental sustainability can be only attained when the maximum digging effort attributes zero marginal revenues while at the same time the total revenues reach a peak level as shown in Figure 9a.

In terms of the open-access scenario, the digging activity will commence once the average digging revenues are higher than the marginal costs and will cease when the cost per unit (marginal cost) is higher than average revenues as presented in Figure 9b. At this point, the total digging costs should also be equalized with total digging revenues. The open-access scenario may offer high total revenues but does not ensure the sustainability of casulo reserves in the long run. Recall that the total revenues are identified with the logistic growth pattern of the species [57].

Also, both the MSY and moreover the open-access scenarios do not foster maximum economic benefits for casulo diggers. As shown in Figure $9 b$, in both cases the marginal revenue line is below the marginal digging costs before it reaches zero levels. In other words, casulo diggers have an economic loss for each extra digging hour they spend once the marginal revenues intersect the marginal costs. Thus, maximum benefits could only be attained at the crossing between the marginal costs and revenues, which is widely known as MEY and can ensure the highest benefits for the diggers in relation to the maximum effort spent for this activity [26].

The attainment of the highest economic benefits can also be explained through the total revenues curve. As presented in Figure 9a, total digging revenues surpass total costs at the highest possible extent by anticipating a sustainable digging in economic and biological terms. It is preconditioned that the Ordinance regulation safeguards the implementation of MEY and MSY scenarios. Also, the costs and revenues generated by the digging effort in all the scenarios are by definition interrelated and thus no statistical indicators of association and significance are required [26].

\section{Conclusions}

Current economic hardships in the region may intensify baitworm digging resulting in significant impact on the stock reserves. It is, however, emphasized that the results are based on bimonthly observations over a one-year period. Furthermore, the bioeconomic analysis was carried out with a simplified and static model where crucial socio-economic and technical parameters were not considered. 
A pure economic analysis on the assessment of decreasing marginal utility of casulo could also be sought. This is implicitly covered in all the research questions of our study. We have also clearly mentioned that the main scope of this work is to improve the current bait digging regulatory policies and an economic analysis focused exclusively on the decreasing marginal utility is beyond the scope of the paper.

The current study could be used as a baseline policy framework of bait digging in the Ria de Aveiro coastal lagoon by applying general inferences to other Portuguese and European aquatic ecosystems practicing similar activities.

Acknowledgments: This study was supported by the European Commission, under the 7th Framework Programme through the collaborative research project LAGOONS (contract No. 283157). Thanks, are also due for the financial support to CESAM - Centre for Environment and Marine Studies (UID/AMB/50017/2013), to FCT/MEC through national funds and the co-funding by the FEDER, within the PT2020 Partnership Agreement and Compete 2020.

Author Contributions: H.Q. has designed and supervised the data collection by A.A. while H.Q., A.I.L. and S.X. conceived the study design and the article structure. S.X. performed the modelling analysis and scenarios and A.I.L. supported the paper development and provided material for the case study. S.X. led the writing of the manuscript with contributions from all authors.

Conflicts of Interest: The authors declare no conflict of interest.

Appendix A. Survey on Casulo Fishing in Aveiro Lagoon 2012-2013
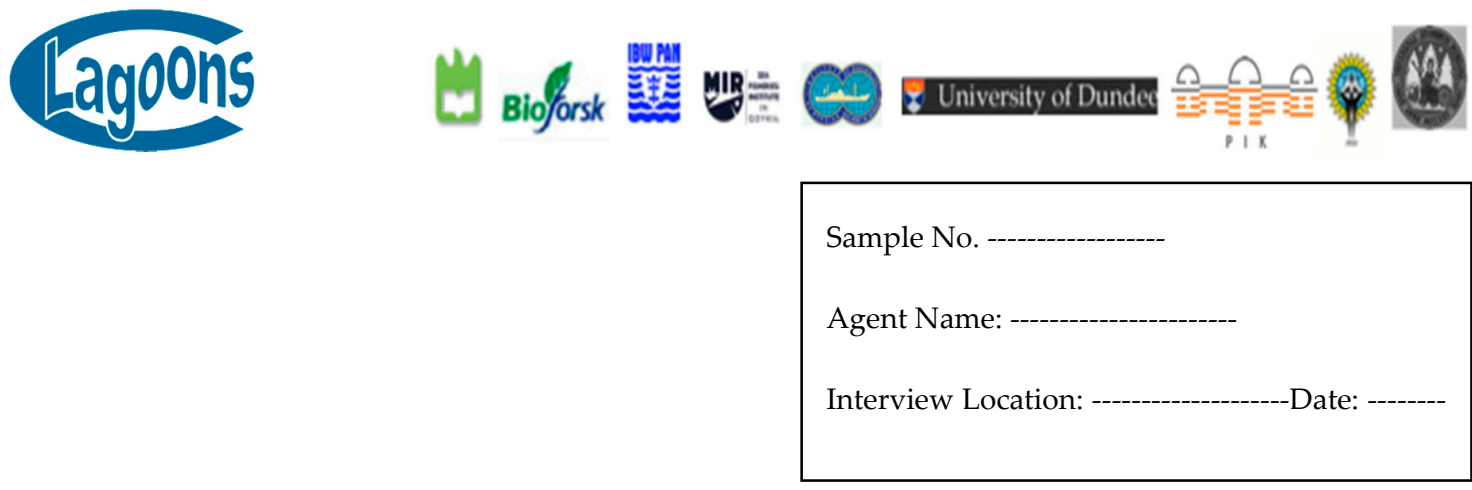

Questionnaire for Bench Mark Survey

\section{General Information}

1.1 Gender:

1.2 Age:

1.3 Area of Residence:

1.4 Primary professional occupation:

1.5 Degree of Studies:

1.6 Bait Fishing Experience (in years):

\section{Digging Activity}

2.1 Frequency of digging activity:

2.2 Duration of the digging session:

2.3 Weight of total capture:

2.4 Number of individuals captured:

2.5 Destination of captures (domestic market/export):

2.6 Expected value of first sale: 


\section{References}

1. Alós, J.; Arlinghaus, R.; Palmer, M.; March, D.; Álvarez, I. The influence of type of natural bait on fish catches and hooking location in a mixed-species marine recreational fishery, with implications for management. Fish. Res. 2009, 97, 270-277. [CrossRef]

2. Leguerrier, D.; Niquil, N.; Petiau, A.; Bodoy, A. Modelling the impact of oyster culture on a mudflat flood web in Marennes Ol'eron Bay (France). Mar. Ecol. Prog. Ser. 2004, 273, 147-162. [CrossRef]

3. Rossi, F.; Forster, R.M.; Montserrat, F.; Ponti, M.; Terlizzi, A.; Ysebaert, T.; Middelburg, J.J. Human trampling as short-term disturbance on intertidal mudflats: Effects on macrofauna biodiversity and population dynamics of bivalves. Mar. Biol. 2007, 151, 2077-2090. [CrossRef]

4. Cunha, T.; Hall, A.; Queiroga, H. Estimation of the Diopatra neapolitana annual harvest resulting from digging activity in Canal de Mira, Ria de Aveiro. Fish. Res. 2005, 76, 56-66. [CrossRef]

5. Freitas, F.; Cunha, T.; Hall, A.; Queiroga, H. Diopatra neapolitana, Importância Sócio-económica e Sustentabilidade das Capturas, no Canal de Mira, Ria de Aveiro. In Proceedings of the Aveiro Jornadas da Ria de Aveiro, Aveiro, Portugal, 13 October 2011.

6. Choe, S. On the life history of the Polychaete worm, Diopatra neapolitana. Bull. Jpn. Soc. Sci. Fish. 1960, 26, 430-437. [CrossRef]

7. Rodrigues, A.M.; Pires, P.; Mendo, S.; Quintino, V. Diopatra neapolitana and Diopatra marocensis from the Portuguese coast: Morphological and genetic comparison. Estuar. Coast. Shelf Sci. 2009, 85, 609-617. [CrossRef]

8. Murray, S.N.; Denis, T.G.; Kido, J.S.; Smith, J.R. Human Visitation and the Frequency and Potential Effects of Collecting on Rocky Intertidal Populations in Southern California Marine Reserves. California Cooperative Oceanic Fisheries Investigations (CalCOFI): CA, USA, 1999; Volume 40, pp. 100-106. Available online: http:/ / calcofi.org/publications / calcofireports/v40/Vol_40_Murray_etal.pdf (accessed on 4 September 2017).

9. Watson, G.J.; Murray, J.M.; Schaefer, M.; Bonner, A. Successful local marine conservation requires appropriate educational methods and adequate enforcement. Mar. Policy 2015, 52, 59-67. [CrossRef]

10. Code of Federal Regulations (CFR), Parks, Forest and Public Policy; U.S. Superintendent of Documents, Office of the Federal Register (OFR) and the Government Publishing Office: Washington, DC, USA, 2005.

11. Rogers, S.I. A Review of Closed Areas in the United Kingdom Exclusive Economic Zone; Science Series Technical Report No. 106; CEFAS-Centre for Environment, Fisheries and Aquaculture Science: Lowestoft, UK, 1997. Available online: https://www.cefas.co.uk/publications/techrep/tech106.pdf (accessed on 17 September 2017).

12. Lancaster, D.; Dearden, P.; Bann, N.C. Drivers of recreational fisher compliance in temperate marine conservation areas: A study of Rockfish Conservation Areas in British Columbia, Canada. Glob. Ecol. Conserv. 2015, 4, 645-657. [CrossRef]

13. Lancaster, D.; Dearden, P.; Haggarty, D.R.; Volpe, J.P.; Ban, N.C. Effectiveness of shore-based remote camera monitoring for quantifying recreational fisher compliance in marine conservation areas. Aquat. Conserv. Mar. Freshw. Ecosyst. 2017, 27, 804-813. [CrossRef]

14. Teles, F.; Santinha, G.; Marques, J.L.; Pinho, L.; Cunha, C.R.; Wolf, J.-H.; Borges, M. Estratégia Integrada de Desenvolvimento Territorial 2014-2020: Quadro Comum de Investimentos da Região de Aveiro; Revisão v.3; Comunidade Intermunicipal da Região de Aveiro: Aveiro, Portugal, 2014.

15. Rudd, M.A.; Tupper, M.H.; Folmer, H.; Van Kooten, G.C. Policy analysis for tropical marine reserves: Challenges and directions. Fish Fish. 2003, 4, 65-85. [CrossRef]

16. Ferse, S.C.; Costa, M.M.; Manez, K.S.; Adhuri, D.S.; Glaser, M. Allies, not aliens-Increasing the role of local communities in marine protected area implementation. Environ. Conserv. 2010, 37, 23-34. [CrossRef]

17. Beukema, J.J. Long-term effects of mechanical harvesting of lugworms Arenicola marina on the zoobenthic community of a tidal flat in the Wadden Sea. Neth. J. Sea Res. 1995, 33, 219-227. [CrossRef]

18. Brown, B.; Wilson, W.H. The role of commercial digging of mudflats as an agent for change of in faunal intertidal populations. J. Exp. Mar. Biol. Ecol. 1997, 218, 49-61. [CrossRef]

19. Ferns, P.N.; Rostron, D.M.; Siman, S.H.Y. Effects of mechanical cockle harvesting on intertidal communities. J. Appl. Ecol. 2000, 37, 464-474. [CrossRef]

20. Watson, G.J.; Farrell, P.; Stanton, S.; Skidmore, L.C. Effects of bait collection on Nereis virens populations and macrofaunal communities in the Solent, UK. J. Mar. Biol. Assoc. 2007, 87, 703-716. [CrossRef] 
21. Navon, M.; Dauvin, J.C. The immediate impact of intertidal pebble fork harvesting on the warty venus Venus verrucosa benthic community. Cah. Biol. Mar. 2013, 54, 385-392.

22. Birchenough, S. Impact of Bait Collecting in Poole Harbour and Other Estuaries within the Southern IFCA District; Southern Inshore Fisheries and Conservation Authority: Dorset, UK, 2013. Available online: https:/ / www.gov.uk/government/uploads/system/uploads/attachment_data/file/312998/fcfbaitcollecting.pdf (accessed on 13 September 2017).

23. Neves de Carvalho, A.; Lino Vaz, A.S.; Boto Sérgio, T.I.; Talhadas dos Santos, P.J. Sustainability of bait fishing harvesting in estuarine ecosystems-Case study in the Local Natural Reserve of Douro Estuary, Portugal. J. Integr. Coast. Zone Manag. 2013, 13, 157-168.

24. Watson, G.J.; Murray, J.M.; Schaefer, M.; Bonner, A. Bait worms: A valuable and important fishery with implications for fisheries and conservation management. Fish Fish. 2016. [CrossRef]

25. Thrush, S.F.; Dayton, P.K. Disturbance to Marine Benthic Habitats by Trawling and Dredging: Implications for Marine Biodiversity. Annu. Rev. Ecol. Syst. 2002, 33, 449-473. [CrossRef]

26. Walters, C.J.; Martell, S.D. Fisheries Ecology and Management; Princeton University Press: Princeton, NJ, USA, 2004.

27. INE-Statistics Portugal. Censos 2011 Resultados Definitivos-Portugal. Census 2011 Final Results-Portugal; Instituto Nacional de Estatística, I.P Editor Publ.: Lisbon, Portugal, 2011.

28. Aleixo, A. Pesca Lúdica e Apanha do Casulo Na Ria de Aveiro: 2012/2013. Master's Thesis, University of Aveiro, Aveiro, Portugal, 2013.

29. Leitao, F.M.; Gaspar, M.B. Immediate effect of intertidal non-mechanised cockle harvesting on macrobenthic communities: A comparative study. Sci. Mar. 2007, 71, 723-733. [CrossRef]

30. Merino, G.; Quetglas, A.; Maynou, F.; Garau, A.; Arrizabalaga, H.; Murua, H.; Santiago, J.; Barange, M.; Prellezo, R.; García, D.; et al. Improving the performance of a Mediterranean demersal fishery toward economic objectives beyond MSY. Fish. Res. 2015, 161, 131-144. [CrossRef]

31. Boldina, I.; Beninger, P.G. Fine-scale spatial distribution of the common lugworm Arenicola marina, and effects of intertidal clam fishing, Estuarine. Coast. Shelf Sci. 2014, 143, 32-40. [CrossRef]

32. Clay, J.W. World Agriculture and the Environment: A Commodity-by-Commodity Guide to Impacts and Practices; Island Press: Washington, DC, USA, 2003.

33. Organisation for Economic Co-operation and Development (OECD). OECD Review of Fisheries: Policies and Summary Statistics 2015; OECD Publishing: Paris, France, 2015.

34. Kuparinen, A.; Boit, A.; Valdovinos, F.; Lassaux, H.; Martinez, N. Fishing-induced life-history changes degrade and destabilize harvested ecosystems. Sci. Rep. 2016, 6, 22245. [CrossRef] [PubMed]

35. Phillipson, J.; Symes, D. Science for sustainable fisheries management: An interdisciplinary approach. Fish. Res. 2013, 139, 61-64. [CrossRef]

36. Squires, D.; Vestergaard, N. Putting Economics into Maximum Economic Yield. Mar. Resour. Econ. 2016, 31, 101-116. [CrossRef]

37. Choquenot, D.; Nicol, S.J.; Koehn, J.D. Bioeconomic modeling in the development of invasive fish policy. N. Z. J. Mar. Freshw. Res. 2004, 38, 419-428. [CrossRef]

38. Pita, A.; Casey, J.; Hawkins, S.J.; Villarreal, M.R.; Gutiérrez, M.J.; Cabral, H.; Carocci, F.; Abaunza, P.; Pascual, S.; Presa, P. Conceptual and practical advances in fish stock delineation. Fish. Res. 2016, 173, 185-193. [CrossRef]

39. Seijo, J.C.; Caddy, J.F. Uncertainty in bio-economic reference points and indicators of marine fisheries. Mar. Freshw. Res. 2000, 51, 477-483. [CrossRef]

40. Russo, T.; Parisi, A.; Garofalo, G.; Gristina, M.; Cataudella, S.; Fiorentino, F. SMART: A Spatially Explicit Bio-Economic Model for Assessing and Managing Demersal Fisheries, with an Application to Italian Trawlers in the Strait of Sicily. PLoS ONE 2014, 9, e86222. [CrossRef] [PubMed]

41. Pires, A.; Freitas, R.; Quintino, V.; Rodrigues, A.M. Can Diopatra neapolitana (Annelida: Onuphidae) regenerate body damage caused by bait digging or predation? Estuar. Coast. Shelf Sci. 2012, 110, 36-42. [CrossRef]

42. Dias, J.M.; Lopes, J.F.; Dekeyser, I. Tidal propagation in Ria de Aveiro Lagoon, Portugal. Phys. Chem. Earth B 2000, 25, 369-374. [CrossRef]

43. AMBIECO/PLRA. Estudo da Caracterização da Qualidade Ecoligica da Ria de Aveiro; Ria de Aveiro POLIS LITORAL, AMBIECO: Aveiro, Portugal, 2011. 
44. Hoenig, J.M.; Robson, D.S.; Jones, C.M.; Pollock, K.H. Scheduling Counts in the Instantaneous and Progressive Count Methods for Estimating Sport fishing Effort. N. Am. J. Fish. Manag. 1993, 13, 723-736. [CrossRef]

45. Pollock, K.H.; Hoenig, J.M.; Jones, C.M.; Robson, D.S.; Greene, C.J. Catch rate estimation for roving and access point surveys. N. Am. J. Fish. Manag. 1997, 17, 11-19. [CrossRef]

46. Cochrane, K.L.; Garcia, S.M. A Fishery Manager's Guidebook; The Food and Agriculture Organization of the United Nations: Rome, Italy; Wiley-Blackwell: Oxford, UK, 2009.

47. Yamaguchi, M. Estimating growth parameters from growth rate data: Problems with marine sedentary invertebrates. Oecologia 1975, 20, 321-332. [CrossRef] [PubMed]

48. Fujita, R.; Thornhill, D.J.; Karr, K.; Cooper, C.H.; Dee, L.E. Assessing and managing data-limited ornamental fisheries in coral reefs. Fish Fish. 2012, 15, 661-675. [CrossRef]

49. Dagli, E.; Ergen, Z.; Cinar, M.E. One year observation on the population structure of, D. neapolitann Delle Chiaje (Polychaeta: Onuphidae) in Izmir Bay (Aegean Sea, eastern Mediterranean). Mar. Ecol. 2006, 26, 265-272. [CrossRef]

50. Begon, M.; Townsed, C.R.; Harper, J.L. Ecology: Individuals, Populations and Communities, 3rd ed.; Wiley-Blackwell: Oxford, UK, 1996.

51. Begon, M.; Townsed, C.R.; Harper, J.L. Ecology: From Individuals to Ecosystems, 4th ed.; Wiley-Blackwell: Oxford, UK, 2006.

52. Caddy, J.F.; Defeo, O. Enhancing or Restoring the Productivity of Natural Populations of Shellfish and Other Marine Invertebrate Resources; Technical Paper No. 448; FAO Fisheries: Rome, Italy, 2003.

53. Flaaten, O. Fisheries Economics and Management, 1st ed.; Bookboon Publ.: Copenhagen, Denmark, 2016, ISBN 978-87-403-1193-8. Available online: http:/ / bookboon.com/en/fisheries-economics-and-managementebook (accessed on 12 August 2017).

54. Clark, C.W. The Worldwide Crisis in Fisheries: Economic Models and Human Behavior; Cambridge University Press: Cambridge, UK, 2006.

55. Pascoe, S.; Vieira, S.; Thebaud, O. Allocating repairs and maintenance costs to fixed or variable costs in fisheries bioeconomic models. Appl. Econ. Lett. 2015, 22, 127-131. [CrossRef]

56. Macher, C.; Boncoeur, J. Optimal Selectivity and Effort Cost: A Simple Bioeconomic Model with an Application to the Bay of Biscay Nephrops Fishery. Mar. Resour. Econ. 2010, 25, 213-232. [CrossRef]

57. Gordon, S. The Economic Theory of a Common-Property Resource: The Fishery. J. Political Econ. 1954, 62, 124-142. [CrossRef] 